\title{
Elaboration and properties of low-cost ceramic microfiltration membrane from local Tunisian clay for wastewater treatment
}

\section{(Elaboração e propriedades de membrana cerâmica de microfiltração de baixo custo com argila tunisina para tratamento de efluentes)}

\author{
N. Kamoun ${ }^{1 *}$, W. Hajjeji ${ }^{2}$, R. Abid ${ }^{I}$, M.A.Rodriguez ${ }^{3}$, F. Jamoussi ${ }^{1}$ \\ ${ }^{I}$ Center of Water Research and Technology, Georesources Laboratory, Borj Cedria Ecopark, \\ BP 273, 8020 Solima, Tunisia \\ ${ }^{2}$ Center of Water Research and Technology, Natural Water Treatment Laboratory, Soliman, Tunisia \\ ${ }^{3}$ Instituto de Cerámica y Vidrio, Madrid, Spain
}

\begin{abstract}
This study focused on the development and preparation of a microfiltration membrane, based on a low-cost natural Tunisian clay powder, deposited on macro-porous ceramic support. The deposit was made through a dip-coating technique, followed by a drying process and sintering at $700{ }^{\circ} \mathrm{C}$. Results revealed that the obtained membrane was characterized by a good adhesion between the membrane layer and the ceramic support, an average pore diameter of $0.34 \mu \mathrm{m}$, and a porosity of $39 \%$. This membrane was applied in the treatment of wastewater generated by the wastewater treatment plant of Sfax, Tunisia. The performances in terms of permeate flux and efficiency were determined in order to reduce the pollutant content expressed in terms of turbidity, biochemical oxygen demand $\left(\mathrm{BOD}_{5}\right)$, and suspended matter (MES). Results showed an MES retention value of about $15 \%$, and turbidity and $\mathrm{BOD}_{5}$ retention rate of $99 \%$ and $\sim 100 \%$, respectively.

Keywords: clay, membrane, microfiltration, ceramic, wastewater.
\end{abstract}

Resumo

Este estudo concentrou-se no desenvolvimento e na preparação de membrana de microfiltração, com base em pó de argila natural da Tunísia de baixo custo, depositado em suporte cerâmico macroporoso. O depósito foi aplicado pela técnica de dip-coating, seguida de processo de secagem e sinterização a $700{ }^{\circ} \mathrm{C}$. Os resultados revelaram que a membrana obtida foi caracterizada por boa adesão entre a camada da membrana e o suporte cerâmico, diâmetro médio de poros de 0,34 um e porosidade de 39\%. Esta membrana foi aplicada no tratamento de efluente gerado pela estação de tratamento de esgoto de Sfax, Tunísia. Os desempenhos em termos de fluxo e eficiência do permeado foram determinados para reduzir o teor de poluentes expresso em termos de turbidez, demanda bioquímica de oxigênio $\left(\mathrm{DBO}_{5}\right)$ e matéria em suspensão (MES). Os resultados mostraram um valor de retenção de MES de cerca de $15 \%$ e turbidez e taxa de retenção de DBO de $99 \%$ e $\sim 100 \%$, respectivamente.

Palavras-chave: argila, membrana, microfiltração, cerâmica, efluentes.

\section{INTRODUCTION}

Nowadays, there is a growing demand for the quantity and quality of drinking and irrigation water because water is important for every living organism to withstand life. Since 1962, membranes have emerged as a water purification medium. In fact, this technology has proven to be faster, more effective, and less costly than the means of traditional separation to meet the needs of water consumption [1, 2]. The membrane processes are now well established, replacing the techniques of conventional separation [3] Today, they are used as a means of separation and filtration in various economic sectors such as agro-food, biotechnology, chemical industry, domestic, and industrial

*kamounnaoufel@yahoo.fr

Dhttps://orcid.org/0000-0003-1515-9148 sewage treatment wastewater causing serious environmental problems and mainly on human health. Indeed, the use of treated wastewater in agriculture can only be beneficial for countries with water scarcity providing the recycling technology is applied. Early research in ceramic membrane fabrication is focused on the utilization of alumina [4, 5], zirconia [6], titania [7], and silica [8]. These ceramic membranes have several advantages, such as chemical stability, durability, high separation efficiency, and are useful in different membrane applications [9-18]. However, the cost of these membranes is very high. For this reason, many researchers have reported the fabrication of ceramic membranes using less expensive, natural, and abundant raw materials such as dolomite [19, 20], attapulgite [21], and natural clay [22, 23].

Several authors investigated the development of ceramic membranes based on natural materials. Achiou et al. [24] 
reported the characterization of flat ceramic membranes elaborated from natural Moroccan pozzolan. Also, Jeong et al. [25] elaborated ceramic membrane supports effectively produced with pyrophyllite and alumina, sintered at $1350{ }^{\circ} \mathrm{C}$ and deposited with alumina powder suspension to obtain a narrow pore size distribution. Mouiya et al. [26] investigated the development of natural Moroccan clay material from the Safi region with the addition of natural phosphate from the Youssoufia region as a porosity agent. In particular, a significant number of papers have been published concerning membranes fabricated using materials based on low-cost raw materials such as clay [27-31], kaolin [32, 33], zeolite [34], dolomite $[35,36]$, etc. Tunisia is highly rich in clay deposits [37]. This substance has proven to be among the essential industrial materials because of their unique physicochemical properties and requires a sintering temperature lower than that required for oxide materials. For instance, it has been mentioned that several clay deposits might constitute good candidates for ceramic and clay product manufacturing [3842]. For this reason, research activities are integrated into the use of clay as membrane material; for example, Ben Ali et al. [43] reported the successful fabrication of low-cost ceramic membrane from Mednine (south of Tunisia) natural kaolinitic-illitic clay with good porosity and mechanical strength (porosity of 35\% and mechanical strength of $6 \mathrm{MPa}$ ).

This study investigated the preparation and characterization of a new microfiltration membrane based on Tunisian clay powder and tested for wastewater filtration. As far as could be ascertained, no studies in the literature have been reported on the development of low-cost microfiltration (MF) ceramic membrane containing only one separative layer from natural clay, especially Tunisian clay.

\section{MATERIALS AND METHODS}

Clay powder: clay was used as raw material extracted from the region of Tabarka in northwestern Tunisia. Characterization of the clay was described elsewhere [44]. It contained, essentially, kaolinite and illite with the presence of some impurities, such as quartz. In addition, the raw clay had a uniform particle size distribution with a maximum at around $d_{50}=3.95 \mu \mathrm{m}$ (Fig. 1). The goal consisted of the realization of a new layer of microfiltration on tubular supports previously elaborated and containing the mentioned clay. The prepared support with a $15 \%$ cellulose volume as a porogen agent was sintered at $850^{\circ} \mathrm{C}$ for $2 \mathrm{~h}$. Its characterization is described elsewhere [44]. The reason behind this choice laid in the fact that the chemical and structural resemblance between the layer and the support would facilitate adhesion during sintering, thus making it possible to obtain similar shrinkages and therefore reducing the risk of residual stresses, deformations or cracks. The mineralogical analyses were carried out by X-ray diffraction technique (XRD) using Philips X'Pert equipment with $\mathrm{CuK} \alpha$ radiation. The relative phase amounts were estimated by measuring the areas of the main diffraction peaks using the Panalytical X'Pert Highscore software. The

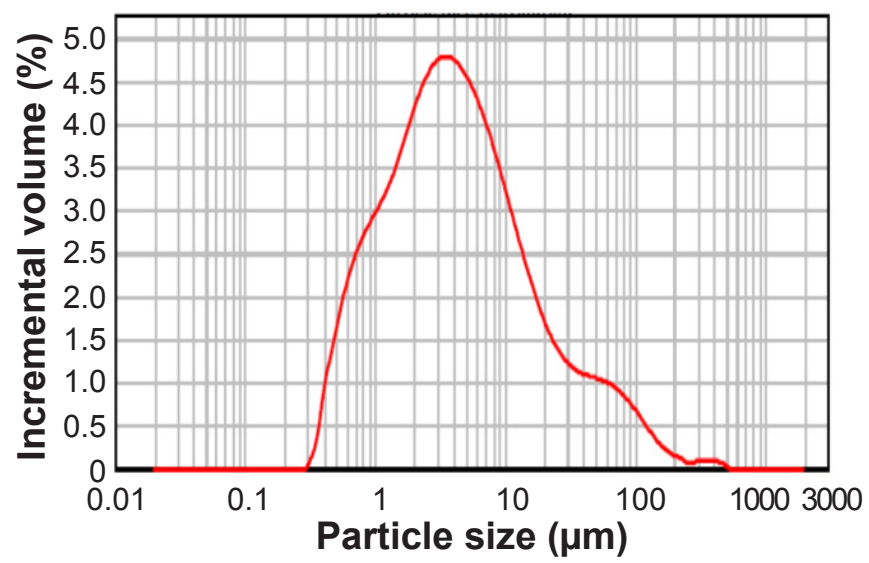

Figure 1: Particle size distribution curve of clay for ceramic support.

[Figura 1: Curva de distribuição granulométrica de argila para suporte cerâmico.]

infrared spectrum was obtained using a Jasco FT-IR-420 spectrophotometer with $1 \mathrm{~cm}^{-1}$ resolution within the 400 to $4000 \mathrm{~cm}^{-1}$ range. $1 \mathrm{mg}$ of the clay fraction was diluted in $200 \mathrm{mg} \mathrm{KBr}$ to prepare pellets. The choice of the mineral powder granulometry depends mainly on the morphological characteristics desired for the ceramic membrane. Clay particle size distribution was determined by laser scattering using Mastersizer S (Malvern, England) equipment. The firing expansion and shrinkage were measured using the Adamel Lhomargy, DM 15 dilatometer.

Membrane preparation: dip-coating is a classical process of ceramic treatment. It is also an easier method applied for large-scale production and can provide a thinner coating layer that is favorable to minimize the additional mass transfer resistance, which results from the coating $[45,46]$. This process allows the development of the filtration layer. The main step consists of preparing the stable suspension from the mineral powder by mixing with distilled water. For improving the dispersion properties of the inorganic material and create homogeneity in the membrane structure, a $1 \%$ volume of tripolyphosphate was added to clay in order to improve dispersity. The deposition of the layers on the supports was performed by dipping. The main challenge in the design of the top layer is to allow its manufacture in a minimum of steps while ensuring chemical and dimensional compatibility with the support. The solid content in the suspension was calculated, taking into account the thickness (l) of the layer to be deposited (Fig. 2). To determine the theoretical solid ratio in suspension, the level of the required clay had to be calculated and adapted to a tubular geometry. The calculation carried out for an inner layer is expressed by the following equations [2]:

$$
\begin{aligned}
& \mathrm{SC}=\mathrm{m} / \mathrm{V}_{\mathrm{H}_{2} \mathrm{O}} \\
& \mathrm{m}=\pi \cdot \mathrm{R}^{2} \cdot 1 \cdot \mathrm{d} \\
& \mathrm{V}_{\mathrm{H}_{2} \mathrm{O}}=\pi \cdot \mathrm{R}^{2} \cdot \mathrm{L} \cdot \mathrm{P}
\end{aligned}
$$


where SC is the solid percentage in suspension, $\mathrm{m}$ the amount of the solid powder, $\mathrm{V}_{\mathrm{H} 2 \mathrm{O}}$ the water volume absorbed by the support, $\mathrm{R}$ is the radius of the support, $\mathrm{L}$ the thickness of the support, 1 the thickness of the top layer, $d$ the density of the top layer, and $\mathrm{P}$ refers to the porosity of the support. Replacing Eqs. B and C in Eq. A:

$$
\mathrm{SC}=1 . \mathrm{d} /(\mathrm{L} . \mathrm{P})
$$

In Eq. D, the solid content percentage in a suspension to obtain a layer with a thickness 1 can be approximately estimated, as long as a complete saturation of the support is reached. In order to evaluate the effect of the thickness of the top layer, $1 \%$ of solid content was prepared to obtain the top layer. In the case of supports, whose average pore size is 2.5 to $0.07 \mu \mathrm{m}$, at least a layer with a thickness of $10 \mu \mathrm{m}$ would be necessary to completely eliminate the influence of the support. Assuming that the density of the clay is $1.3 \mathrm{~g} . \mathrm{cm}^{-3}$, the porosity of the support is equal to $40 \%$ (Table I), the external and internal radius of the support of 5 and $2.5 \mathrm{~mm}$, respectively, it was obtained that the suspension must have a solid content of $1 \%$ in the layer deposited internally.

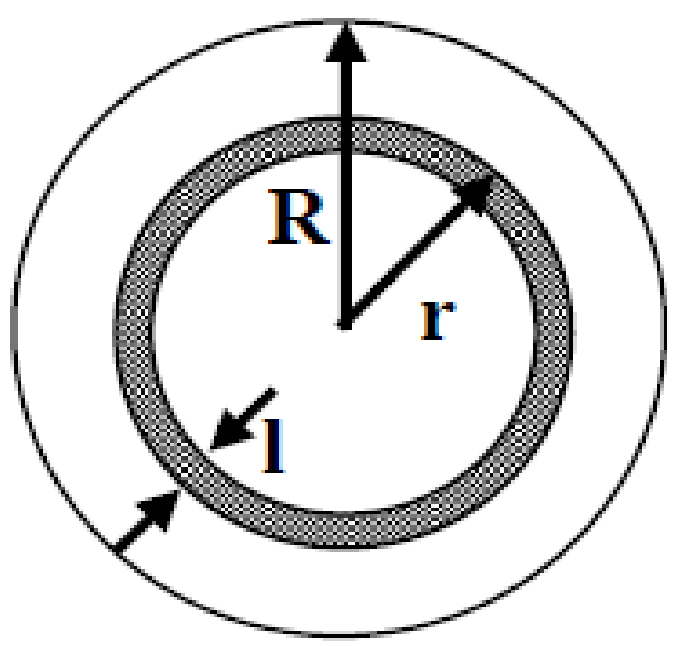

Figure 2: Scheme of the top layer on tubular support.

[Figura 2: Esquema da camada superior no suporte tubular.]

The thermal treatment ensured the layer consolidation and its adhesion to the support already prepared. The program was obtained after a large number of firing tests. The obtained membrane was dried in a stove at $40{ }^{\circ} \mathrm{C}$ for $1 \mathrm{~h}$ and then sintered at $700{ }^{\circ} \mathrm{C}$ for $2 \mathrm{~h}$ to stabilize

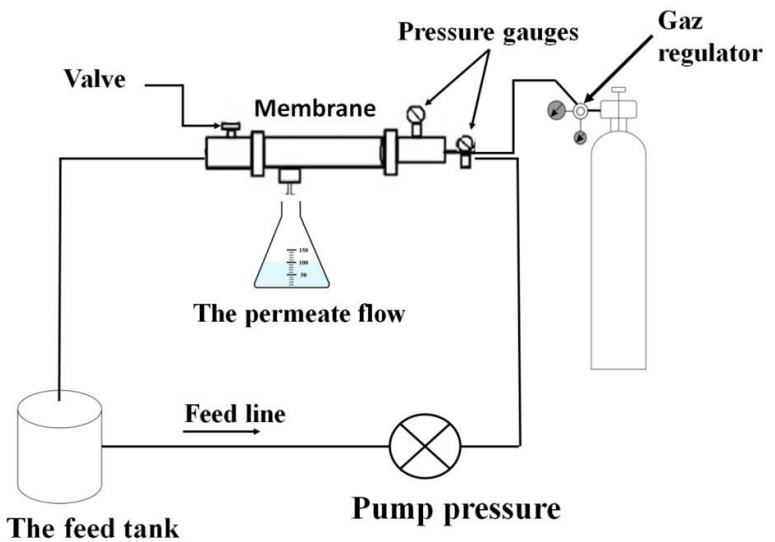

Figure 3: Schematic representation of the cross-flow system of the tubular membrane.

[Figura 3: Representação esquemática do sistema para medida de fluxo tangencial de membrana tubular.]

the structure with a heating/cooling rate of $5{ }^{\circ} \mathrm{C} / \mathrm{min}$. The choice of this temperature $\left(700{ }^{\circ} \mathrm{C}\right)$ was based on the results obtained by dilatometry. In this temperature, we may obtain a porous top layer avoiding the glassy phase. Hubadillah et al. [47] have discussed in detail in their recently published review paper the lower thermal processing temperatures of clay, when compared with most conventional oxide ceramics, and the morphology of decomposition products, namely spinel and mullite, which are of key importance in the development of new membranes [47]. The membrane morphology characterization was carried out using scanning electron microscopy (SEM, TM 1000, Hitachi, Japan). Total porosity, apparent density, and pore size distribution of the obtained ceramic supports were determined by mercury porosimetry (Autopore II 9215, Micromeritics, USA). Tangential filtration tests were conducted using a filter of pilot laboratory scale (Fig. 3) at $25{ }^{\circ} \mathrm{C}$ with an adjustable flow electric pump. The water flux through the support was measured according to time at different transmembrane pressure values; before carrying out the filtration tests, the membrane was conditioned by immersion in distilled water for at least $24 \mathrm{~h}$.

Effluent characterization: ceramic membranes were applied to the wastewater of a treatment plant located in Sfax, Tunisia. To assess the MF membrane performance, analyses were carried out on each sample (input effluent $\mathrm{A}$, treatment plant output effluent $\mathrm{B}$, and the effluent after filtration by the microfiltration membrane $\mathrm{C}$ ).

Table I - Main properties of the support and top layer.

[Tabela I - Propriedades principais do suporte e da camada superior.]

\begin{tabular}{cccc}
\hline Part & Pore diameter $(\mu \mathrm{m})$ & Total porosity $(\%)$ & Apparent density $\left(\mathrm{g} / \mathrm{cm}^{3}\right)$ \\
\hline Top layer & $0.034 \pm 0.05$ & $39 \pm 1$ & $1.70 \pm 0.05$ \\
Support & $2.5,0.070 \pm 0.005$ & $40 \pm 2$ & $1.85 \pm 0.05$ \\
\hline
\end{tabular}


Turbidity was measured using the TN-100/T-100 device and conductivity and $\mathrm{pH}$ determined with a conductivity meter (Noor, mod. 123) and $\mathrm{pH}$ meter, respectively. The chemical oxygen demand (COD) was determined by the reflux flow method using a Fisher Bioblock Sci. reactor (10119 type COD meter), while the biochemical oxygen demand (BOD) was measured according to the manometric method using a BOD meter (type BMS). The retention values were calculated according to the formula:

$$
\mathrm{R}(\%)=\left(1-\frac{\mathrm{C}_{\mathrm{p}}}{\mathrm{C}_{\mathrm{f}}}\right) \cdot 100
$$

where $C_{P}$ is the pollutant concentration in permeate and $C_{f}$ the pollutant concentration in feed solution.

\section{RESULTS AND DISCUSSION}

Clay characterization: the particle size distribution curve of the clay used for the membrane production process is illustrated in Fig. 4. Most particles had a diameter below $40 \mu \mathrm{m}$, and the average particle size of clay was $\mathrm{d}_{50}=2.3 \mu \mathrm{m}$. The particle size distribution of the top layer should not be very large compared to the pore size of the ceramic support. A particle size much larger than the pore size would cause very few particles to penetrate the pores of the layer [38]. Consequently, the adhesion of the deposited layer would not be good, and there would be a danger of delamination. The IR absorption profile is illustrated in Fig. 5; it exhibits the presence of a quartz band at $796 \mathrm{~cm}^{-1}$. The $\mathrm{OH}$ stretching region showed the overlapping of several absorption clay bands constituting the sample: 3 absorption bands of kaolinite in the 3693 to $3649 \mathrm{~cm}^{-1}$ wavenumber range [48] and a single $\mathrm{OH}$ band of illite $\left(3620 \mathrm{~cm}^{-1}\right)$. Kaolinite displays one stretching $\mathrm{Si}-\mathrm{O}$ vibration band at $1114 \mathrm{~cm}^{-1}[48,49]$. The absorption band close to $935 \mathrm{~cm}^{-1}$ attributed to Al-OH vibrations is present in the infrared spectrum, thus indicating the dioctahedral character of clay (dioctahedral smectite, illite, and kaolinite). The band of water molecule $\mathrm{H}_{2} \mathrm{O}$ $\left(1635 \mathrm{~cm}^{-1}\right)$ suggested a high degree of sample hydration, while the carbonate band at $1406 \mathrm{~cm}^{-1}$ was present in the raw sample. Clay chosen for the preparation of the top layer was calcined at $700{ }^{\circ} \mathrm{C}$ and characterized by X-ray diffraction (Fig. 6). The results of calcined clay were compared with those of untreated clay. After thermal treatment, the results showed the disappearance of the kaolinite peaks and the appearance of those corresponding to metakaolinite, with the persistence of quartz peaks. According to bibliographic data, the 450 to $700{ }^{\circ} \mathrm{C}$ range [50] is associated mainly with kaolinite dehydroxylation, which yields metakaolinite. The reaction by which this dehydroxylation occurs is:

$$
\mathrm{Al}_{2} \mathrm{O}_{3} \cdot 2 \mathrm{SiO}_{2} \cdot 2 \mathrm{H}_{2} \mathrm{O} \rightarrow \mathrm{Al}_{2} \mathrm{O}_{3} \cdot 2 \mathrm{SiO}_{2}+2 \mathrm{H}_{2} \mathrm{O}
$$

The X-ray diffractogram also showed the absence of organic matter in the raw material, which was responsible

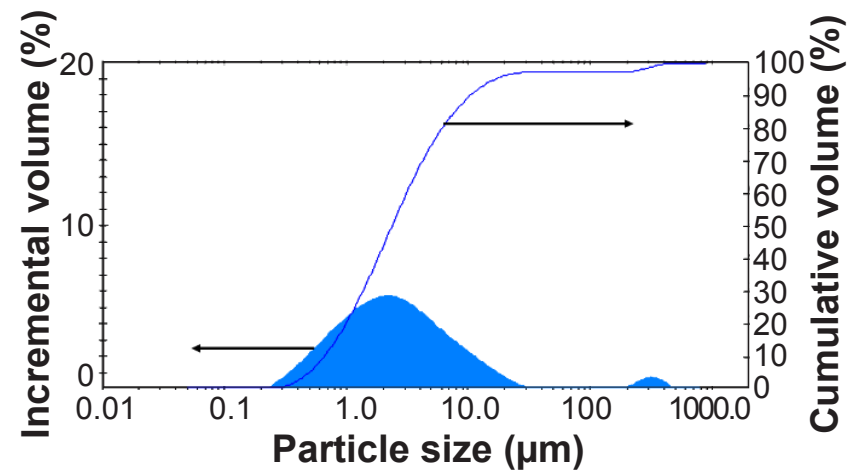

Figure 4: Particle size distribution curves of clay for the top layer.

[Figura 4: Curvas de distribuição granulométrica da argila para a camada superior.]

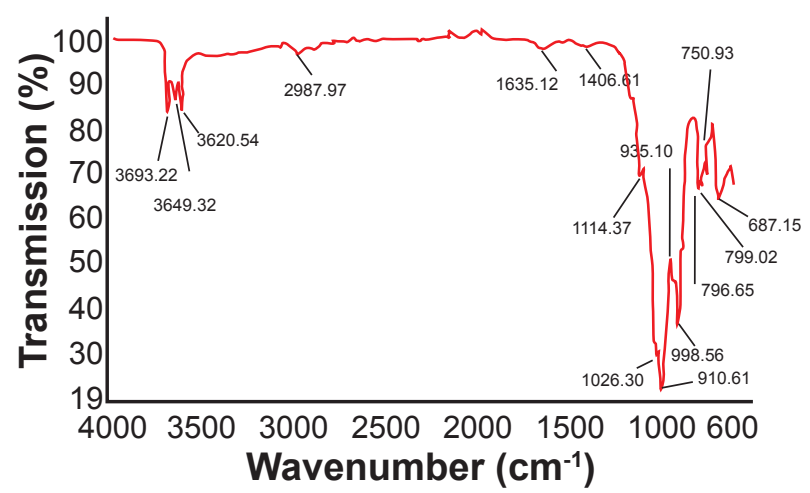

Figure 5: IR spectrum of raw clay.

[Figura 5: Espectro de IR da argila.]

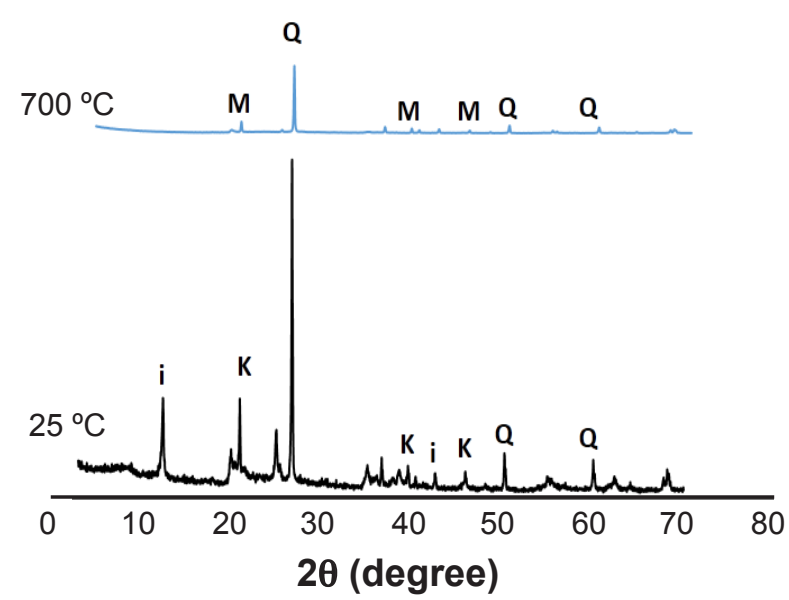

Figure 6: X-ray diffraction patterns of raw clay and clay calcined at $700{ }^{\circ} \mathrm{C}$. K: kaolinite, Q: quartz, i: illite, M: metakaolinite.

[Figura 6: Padrões de difração de raios $X$ da argila bruta e argila calcinada a $700{ }^{\circ} \mathrm{C}$. K: caulinita, Q: quartzo, i: illita, M: metacaulinita.]

for a porosity lower than that of the support during sintering.

Active layer characterization: SEM images of the prepared membranes are shown in Fig. 7 revealing the texture of the elaborated membrane surface, where its macroporous structure is clearly visible with the scanning electron microscope. The cross-sectional view of the clay ceramic 
membrane is presented in Fig. 7a. Following coating, the top layer had a finer structure because of the smaller particle size of the clay with strong adhesion to the support. Besides, it clearly presented a regular aspect from the point of view of thickness without defects, cracks, or delamination between the coating and support layers (Fig. 7b). It can be seen that the pore distribution was uniform with a microfiltration layer thickness of about $10 \mu \mathrm{m}$. This thickness value is considered acceptable for a top layer. In fact, it met the requirements for the elimination of the support roughness. The images also revealed a high consolidation obtained at sintered temperature, with the top layer eliminating all support irregularities and macropores. Mercury intrusion porosimetry was used to estimate the final pore size distribution, total porosity, pore diameter, and apparent density. The results are listed in Table I. It was noticed that the apparent density of the support $\left(1.85 \pm 0.05 \mathrm{~g} / \mathrm{cm}^{3}\right)$ was greater than that of the top layer $\left(1.70 \pm 0.05 \mathrm{~g} / \mathrm{cm}^{3}\right)$. This can be explained by densification in the solid phase. Indeed the sintering temperature of the upper layer must be lower than
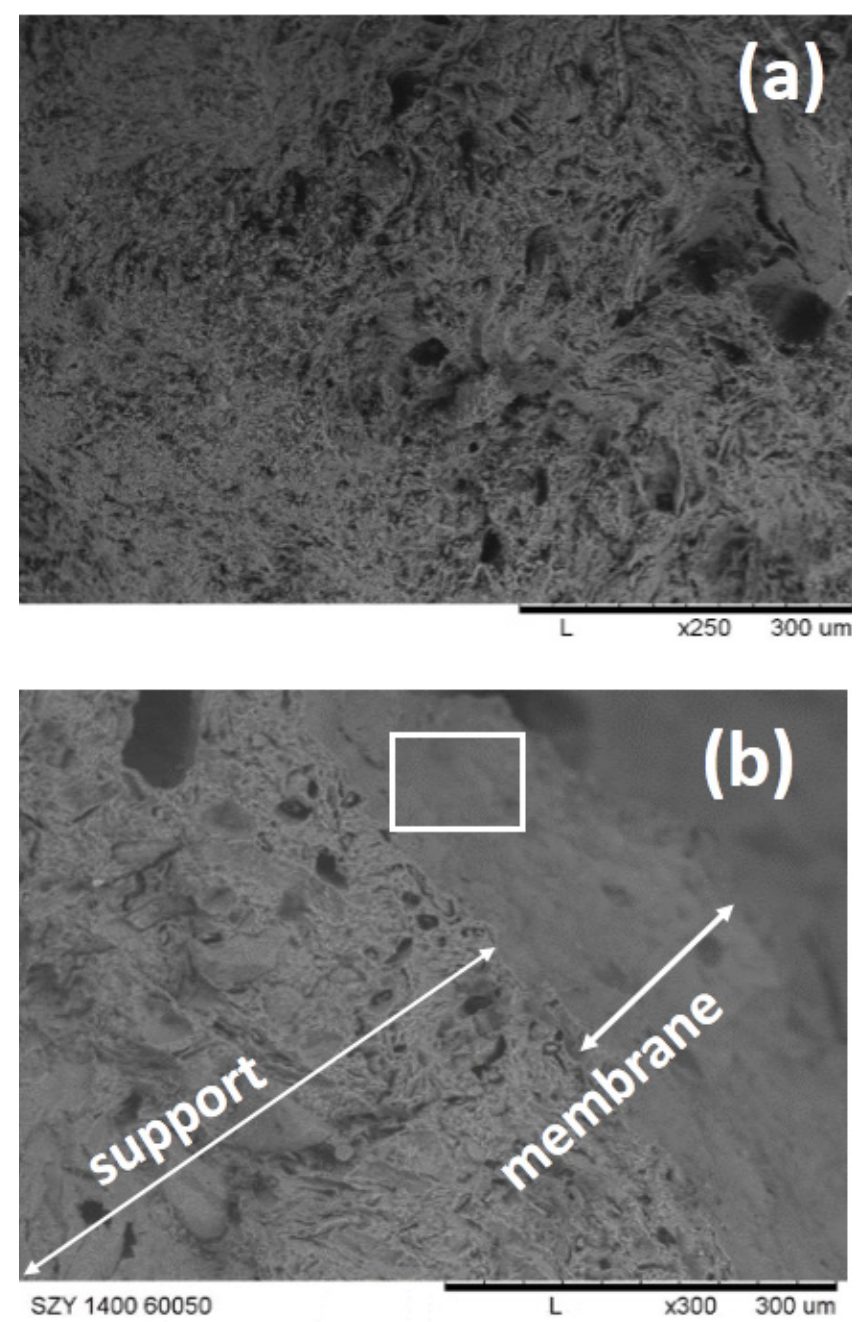

Figure 7: SEM micrographs of the membrane sintered at $700{ }^{\circ} \mathrm{C}$ : a) surface of the top layer; and b) lateral view.

[Figura 7: Micrografias de MEV da membrana sinterizada a $700{ }^{\circ} \mathrm{C}$ : a) superfície da camada superior; e b) vista lateral.] that of the support since the latter must be high enough to ensure adhesion. In addition, the support presented a higher value of density that is explained by the formation of the glassy phase due to the presence of impurities in the raw clay. The total porosity of the support sintered at $850{ }^{\circ} \mathrm{C}$ was $40 \% \pm 2 \%$, showing a bimodal distribution of pore size with diameters of 2.5 and $0.070 \pm 0.005 \mu \mathrm{m}$ [39], compared with the top layer, which total porosity sintered at $700{ }^{\circ} \mathrm{C}$ was $39 \% \pm 1 \%$, showing a monomodal distribution of pore size with a diameter of $0.034 \pm 0.005 \mu \mathrm{m}$. In fact, such a narrow pore size with satisfying porosity helped to obtain a highly selective membrane that can be used for microfiltration.

Application to effluent treatment: hydraulic permeability, $\mathrm{L}_{\mathrm{p}}\left[\mathrm{L} /\left(\mathrm{h} \cdot \mathrm{m}^{2} \cdot\right.\right.$ bar $\left.)\right]$, is an important parameter for defining the operating conditions and performance of the membrane. It can be determined using the distilled water flux variation $\left(\mathrm{J}_{\mathrm{w}}\right)$ with the transmembrane pressure $\Delta \mathrm{P}$ (bar) following Darcy's law:

$$
\mathrm{J}_{\mathrm{w}}=\mathrm{L}_{\mathrm{p}} \cdot \Delta \mathrm{P}
$$
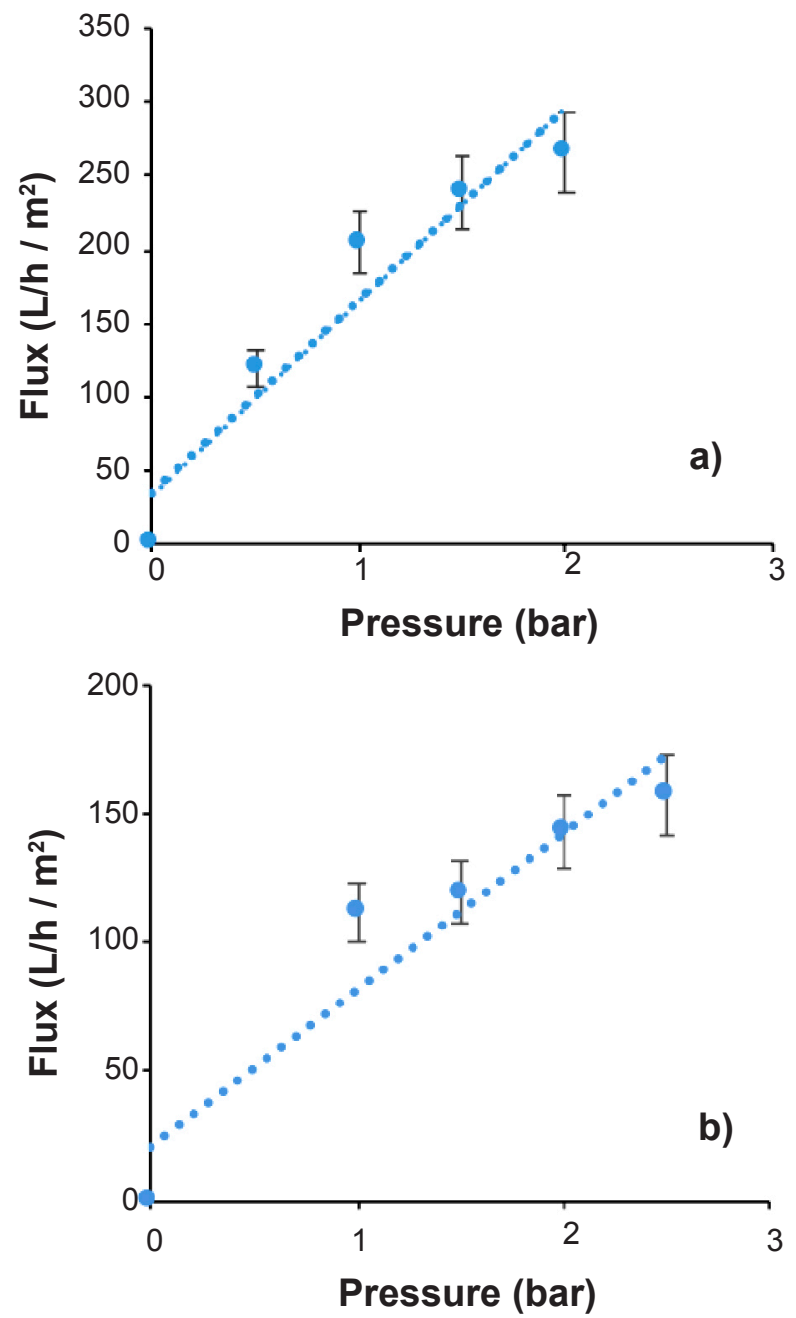

Figure 8: Permeate flow for porous top layer membrane with: a) distilled water; and b) wastewater.

[Figura 8: Fluxo de permeado para membrana porosa da camada superior com: a) água destilada; e b) água residual.] 
So as to obtain a rapid stabilization of the permeate flow, the tested membrane was immersed in pure water during the $24 \mathrm{~h}$ preceding filtration. The water permeation flow evolution, according to the transmembrane pressure, allowed to study the variation of the membrane water flow measured within 0 to 2 bar pressure range (Fig. 8a). Permeate flux increased linearly with the transmembrane pressure in the pressure range studied.

Wastewater filtration with ceramic membrane: Fig. $8 \mathrm{~b}$ illustrates the variation of the wastewater permeation flow according to the transmembrane pressure range of 0 to 2.5 bar. The permeate flux increased linearly with the transmembrane pressure until a 2 bar value and then stabilized at a value of $\sim 140 \mathrm{~L} \cdot \mathrm{h}^{-1} \cdot \mathrm{m}^{-2}$. The permeate flux decreased by only $14 \%$. This behavior can be explained by the formation of a concentrated polarization layer. The fouling has not been studied, but it is expected to be quite high due to the size and wide distribution of the pores. The characteristics of wastewater effluent before and after filtration are reported in Table II. As can be seen, the input effluent A had high turbidity (114 NTU)

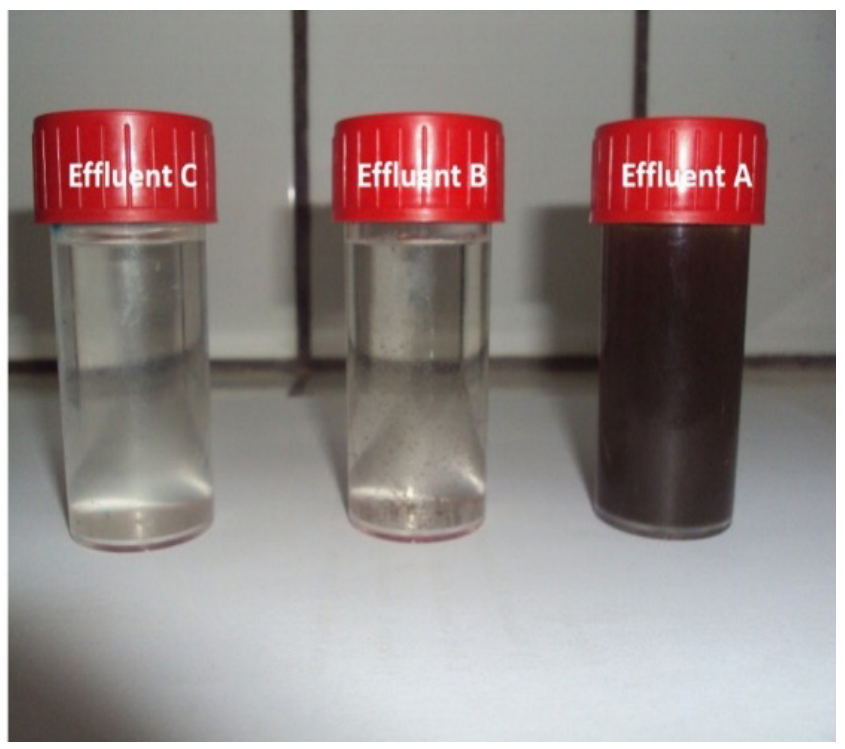

Figure 9: Image of effluents before and after treatment using microfiltration membrane: A) input effluent of the treatment plant; B) output effluent of the treatment plant; and C) effluent after filtration by the microfiltration membrane.

[Figura 10: Imagem dos efluentes antes e após o tratamento usando a membrana de microfiltração: A) efluente de entrada da estação de tratamento; $B$ ) efluente de saída da estação de tratamento; $e$ C) efluente após filtração pela membrana de microfiltração.] due to the high amount of the suspended material (63 $\mathrm{mg} / \mathrm{L})$, which was responsible for the effluent coloration. The microfiltration membrane showed that the turbidity removal percentage was $99 \%$ for $1 \mathrm{~h}$ of filtration, which was greater than that of effluent B (treatment plant output). Besides, Fig. 9 shows a noticeable elimination of suspended matter illustrated by the change of the effluent color. Therefore, the membrane allowed an almost complete elimination of suspended solids present in the effluent because the presence of colloidal particles in the effluents is responsible for coloration and turbidity. Hence, the proportional relationship between color and turbidity was confirmed. Values of $\mathrm{pH}$ were not significantly changed for effluents $\mathrm{A}, \mathrm{B}$, and $\mathrm{C}$. Concerning COD, higher values were observed for effluents $\mathrm{A}$ and $\mathrm{B}$ compared with effluent $\mathrm{C}$ (after filtration with MF membrane). This could be attributed to better adsorption of organic molecules on the ceramic membrane. A high retention rate was also observed as regards $\mathrm{BOD}_{5}(\sim 100 \%)$. Comparing the result obtained in this study with those obtained by other researchers, it can be inferred that the membrane obtained at $700{ }^{\circ} \mathrm{C}$ is suitable for water and wastewater treatment [9].

\section{CONCLUSIONS}

A novel microfiltration membrane was prepared by the dip-coating method using the same support material, but differing in mean pore diameter, which was $34 \mathrm{~nm}$. The main objective of this paper was to examine and compare the efficiency of the ceramic membrane in the treatment of wastewater generated by the treatment plant of Sfax. This membrane showed a high performance in terms of permeate flux and efficiency. The results demonstrated high retention rates of biochemical oxygen demand $\left(\mathrm{BOD}_{5}\right)$ and chemical oxygen demand (COD) and high reduction in turbidity and color of effluent, indicating that, with this membrane, high performances can be obtained not only at relatively low pressure (only 2 bar), but also with low-cost compared with those of literature. It can be concluded that the performance of the microfiltration membrane treatment reactor can achieve reductions in $\mathrm{BOD}_{5}$ and turbidity by $\sim 100 \%$ and $99 \%$, respectively. According to the results obtained, the microfiltration membrane-filtered wastewater had better characteristics than effluent filtered by the plant. These results provide significant opportunities to develop ceramic

Table II- Characteristics of the wastewater effluent before and after the filtration process.

[Tabela II - Características do efluente das águas residuais antes e depois do processo de filtração.]

\begin{tabular}{cccccc}
\hline Effluent & Turbidity (NTU) & $\mathrm{pH}$ & MES $(\mathrm{mg} / \mathrm{L})$ & BOD $_{5}(\mathrm{mg} / \mathrm{L})$ & COD $(\mathrm{mg} / \mathrm{L})$ \\
\hline A & 114 & 6.7 & 63 & 175 & 253 \\
B & 55.1 & 7.2 & 35 & 100 & 216 \\
C & 0.99 & 7.3 & 10 & $<1$ & 110 \\
\hline
\end{tabular}

MES: suspended matter; $\mathrm{BOD}_{5}$ : biochemical oxygen demand; $\mathrm{COD}$ : chemical oxygen demand. 
microfiltration membranes for industrial applications.

\section{ACKNOWLEDGMENTS}

This work has been partially supported by the Ministry of Economy and Competitiveness of Spain under project MAT2013-48426-C2-1R and the project Medyna "MaghrebEU research staff exchange on geodynamics, geohazards, and applied geology in Northwest Africa".

\section{REFERENCES}

[1] T. Zsirai, H. Qiblawey, P. Buzatu, J. Al Marri, S.J. Judd, J. Petrol. Sci. Eng. 166 (2018) 283.

[2] J.M. Benito, A. Conesa, M.A. Rodriguez, J. Mater. Sci. 40 (2005) 6105.

[3] M. Sayehi, R.D. Sahnoun, S. Fakhfakh, S. Baklouti, Ceram. Int. 44 (2018) 5202.

[4] K.A. DeFriend, M.R. Wiesner, A.R. Barron, J. Membr. Sci. 224 (2003) 11.

[5] T.V. Gestel, C. Vandecasteele, A. Buekenhoudt, C. Dotremont, J. Luyten, R. Leysen, B.V. Bruggen, G. Maesc, J. Membr. Sci. 207 (2002) 73.

[6] C. Falamaki, A.M. Shafiee, A. Aghaie, J. Eur. Ceram. Soc. 24 (2004) 2285.

[7] Y.H. Wang, T.F. Tian, X.Q. Liu, G.Y. Meng, J. Membr. Sci. 280 (2006) 261.

[8] Y. Yoshino, T. Suzuki, B.N. Nair, H. Taguchi, N. Itoh, J. Membr. Sci. 267 (2005) 8.

[9] P. Belibi Belibi, M.M.G. Nguemtchouin, M. Rivallin, J. Ndi Nsami, J. Sieliechi, S. Cerneaux, M. Cretin, Ceram. Int. 41 (2015) 2752.

[10] Y.H. Wang, X.Q. Liu, G.Y. Meng, Mater. Sci. Eng. A 445-446 (2007) 611.

[11] Y. Dong, S. Chen, X. Zhang, J. Yang, X. Liu, G. Meng, J. Membr. Sci. 281 (2006) 592.

[12] A. Majouli, S. Tahiri, S. Alami Younssi, H. Loukili, A. Albizane, Ceram. Int. 38 (2012) 4295.

[13] L. Gyeong-Taek, H.G. Jeong, I.S. Hwang, D.H. Kim, N. Park, J. Cho, Desalination 238 (2009) 53.

[14] A. Kayvani Fard, G. McKay, A. Buekenhoudt, H. Al Sulaiti, F. Motmans, M. Khraisheh, M. Atieh, Materials 11 (2018) 74.

[15] G. Pasternak, J. Greenman, I. Ieropoulos, Chem. Sus. Chem. 9 (2015) 88.

[16] L. Zhu, M. Chen, Y. Dong, C.Y. Tang, A. Huang, L. Li, Water Res. 90 (2016) 277.

[17] X. Yang, S. Zhou, M. Li, R. Wang, Y. Zhao, Sep. Purif. Technol. 175 (2017) 435.

[18] M.M. Lorente-Ayza, M.J. Orts, V. Pérez-Herranz, S. Mestre, J. Eur. Ceram. Soc 35 (2015) 2333.

[19] T. Mohammadi, A. Pak, Separ. Purif. Tech. 30 (2003) 241.

[20] B.K. Nandi, R. Uppaluri, M.K. Purkait, Appl. Clay Sci. 42 (2008) 102.

[21] B. Fan, H. Hao, A. Guo, R. Yang, J. Water Reuse Desal. 6, 3 (2016) 399.
[22] A. Belouatek, N. Benderdouche, A. Addou, A. Ouagued, N. Bettahar, Micropor. Mesopor. Mat. 85 (2005) 163.

[23] M. Aissat, S. Hamouda, N. Bettahar, B.J. Abu Tarboush, A. Bahmani, Cerâmica 65, 376 (2019) 554.

[24] B. Achiou, H. Elomari, M. Ouammou, A. Albizane, J. Bennazha, S. Alami Younssi, I.E. El Amrani, A. Aaddane, J. Mater. Environ. Sci. 7 (2016) 196.

[25] Y. Jeong, S. Lee, S. Hong, C. Park, J. Membr. Sci. 536 (2017) 108.

[26] M. Mouiya, A. Abourriche, A. Benhammou, Y. El Hafiane, Y. Abouliatim, L. Nibou, M. Oumam, H. Hannache, A. Smith, Desalin. Water Treat. 83 (2017) 277.

[27] M. Mouiya,A. Bouazizi,A.Abourriche,A. Benhammou, Y. El Hafiane, M. Ouammou, Y. Abouliatim, S.A. Younssi, H. Hannache, Mater. Chem. Phys. 227 (2019) 291.

[28] A. Elgamouz, N. Tijani, Micropor. Mesopor. Mater. 271 (2018) 52.

[29] J.D. de Oliveira Henriques, M.W. Pedrassani, W. Klitzke, A.B. Mariano, J.V.C. Vargas, R.B. Vieira, Appl. Clay Sci. 150 (2017) 217.

[30] Y. Zhu, D. Chen, Ceram. Int. 43 (2017) 9465.

[31] S. Mestre, A. Gozalbo, M.M. Lorente-Ayza, E. Sánchez, J. Eur. Ceram. Soc. 39 (2019) 3392.

[32] S.B. Rekik, S. Gassara, J. Bouaziz, A. Deratani, S. Baklouti, Appl. Clay Sci. 143 (2017) 1.

[33] M.A. Abdulhameed, M.H.D. Othman, A.F. Ismail, T. Matsuura, Z. Harun, M.A. Rahman, J. Jaafar, J. Aust. Ceram. Soc. 53 (2017) 645.

[34] L. Peng, X. Xu, X. Yao, H. Liu, X. Gu, J. Membr. Sci. 549 (2018) 446.

[35] C. Kadiri, A. Harabi, F. Bouzerara, J. Aust. Ceram. Soc. 56 (2019) 379.

[36] N. Malik, V.K. Bulasara, S. Basu, Ceram. Int. 46 (2020) 6889 .

[37] K. Jeridi, A. López-Galindo, M. Setti, F. Jamoussi, Appl. Clay Sci. 87 (2014) 292.

[38] H. Baccour, M. Medhioub, F. Jamoussi, T. Mhiri, J. Mater. Process. Technol. 209 (2009) 2812.

[39] M. Eloussaief, N. Fakhfakh, A. Sdiri, S. Bouaziz, M. Benzina, Trans. Indian Ceram. Soc. 71 (2012) 195.

[40] F. Hammami-Ben Zaied, R. Abidi, N. Slim-Shimi, A.K. Somarin, Appl. Clay Sci. 112-113 (2015) 1.

[41] S. Mahmoudi, E. Srasra, F. Zargouni, Appl. Clay Sci. 42 (2008) 125.

[42] B. Moussi, W. Hajjaji, M. Hachani, N. Hatira, J.A. Labrincha, J. Yans, F. Jamoussi, J. Afr. Earth Sci. 164 (2020) 103775.

[43] M. Ben Ali, N. Hamdi, M.A. Rodríguez, K. Mahmoudi, E. Srasra, Ceram. Int. 44 (2018) 2328.

[44] N. Kamoun, M.A. Rodríguez, F. Jamoussi, Desalin. Water Treat. 57 (2016) 28071.

[45] K. Lindqvist, E. Lidén, J. Eur. Ceram. Soc. 17 (1997) 359.

[46] J. Luyten, J. Cooymans, C. Smolders, S. Vercauteren, E.F. Vansant, R. Leysen, J. Eur. Ceram. Soc. 17 (1997) 273. [47] S.K. Hubadillah, M.H.D. Othman, T. Matsuura, A.F. Ismail, M.A. Rahman, Z. Harun, J. Jaafar, M. Nomura, 
Ceram. Int. 44 (2018) 4538.

[48] E. Balan, A.M. Saitta, F. Mauri, G. Calas, Am. Mineral. 86 (2001) 1321.

[49] Y. Deng, J.B. Dixon, G. Norman White, R.H. Loeppert, A.R.S. Juo, Colloids Surf. A Physicochem. Eng. Asp. 281
(2006) 82.

[50] D.N. Todor, Thermal analysis of minerals, Abacus Press, Kent (1976).

(Rec. 27/10/2019, Rev. 18/04/2020, 13/05/2020, Ac. $16 / 05 / 2020)$ 